\title{
The Collapse of Fannie MaE and Freddie Mac: VICTIMS OR VILLAINS?
}

\author{
DALE ARTHUR OESTERLE*
}

\section{INTRODUCTION}

Two government-sponsored enterprises (GSEs), the Federal National Mortgage Association (commonly called Fannie Mae) and the Federal Home Loan Mortgage Corporation (commonly called Freddie Mac) collapsed on September 7, 2008. ${ }^{1}$ On that date, the Director of the Federal Housing Finance Agency (FHFA), James B. Lockhart III, put the two GSEs under the conservatorship of the FHFA and dismissed the firm's chief executive officers and boards of directors. He also forced the firms to issue $79.9 \%$ of their equity to the United States Treasury in exchange for cash infusions and credit guarantees that have ballooned to a mind-numbing $\$ 400$ billion. ${ }^{2}$ Additional purchases of GSE held securities and GSE issued debt by the Federal Reserve and the Treasury put the total price-tag of the government takeover at over $\$ 1.1$ trillion. $^{3}$

The government bailout was a response to the threat of a tsunami of losses. The two GSEs, at the time of the government takeover, held between them ownership of, guarantees on, or securities backed by over half of the United States' $\$ 12$ trillion residential mortgages. ${ }^{4}$ Investors the world over, which included several major foreign governments, held over

\footnotetext{
* J. Gilbert Reese Chair in Contract Law, The Ohio State University Moritz College of Law.

${ }^{1}$ Press Release, Fed. Hous. Fin. Agency, Statement of FHFA Director James B. Lockhart III (Sept. 7, 2008).

${ }^{2}$ Id:; The Present Condition and Future Status of Fannie Mae and Freddie Mac: Hearing Before the Subcomm. on Capital Mkts. of the H. Comm. On Fin. Servs., 111 th Cong. (2009) [hereinafter The Present Condition and Future Status of Fannie Mae and Freddie Mac] (statement of James B. Lockhart, Director, Federal Housing Finance Agency); Press Release, U.S. Dept. Treasury, Office of Public Affairs, Fact Sheet: Treasury Senior Preferred Stock Purchase Agreement (Sept. 7, 2008).

${ }^{3}$ See The Future of the Mortgage Marketing. and the Housing Enterprises: Hearing Before S. Comm. on Banking, Hous. and Urban Affairs, 111 th Cong. 5 (2009) [hereinafter Future of the Mortgage Market and Housing Enterprises] (statement of Edward J. DeMarco, Acting Director, Federal Housing Finance Agency); Peter J. Wallison \& Charles W. Calomiris, The Last Trillion-Dollar Commitment: The Destruction of Fannie Mae and Freddie Mac, 15 J. STRUCTURED FIN. 71 (2009).

${ }^{4}$ See Future of the Mortgage Market and Housing Enterprises, supra note 3, at 5.
} 
$\$ 5.4$ trillion in debt securities backed by the two companies. ${ }^{5}$ The collapse had substantial foreign policy ramifications. The largest foreign investor in United States debt, China, for example, also held large amounts of GSE debt. ${ }^{6}$ Virtually every home mortgage lender in the United States relied on the GSEs to provide liquidity to the residential mortgage market.

Whether the bailout was effective in avoiding deeper, widespread losses will be argued by economists for ages. We do know, however, that the collapse of Fannie and Freddie happened in the third quarter of 2008, initiating the start of the Recession of 2008 from which, as of this writing, our economy has yet to recover. The trigger for the Recession of 2008 was the radical increase in mortgage defaults on residential property, felt harshest in four states (Arizona, California, Florida and Nevada). ${ }^{7}$ The defaults caused losses far beyond their nominal amounts because the mortgage payments were the reference assets of several types of pyramiding derivative securities, which simultaneously plummeted in value due to the increase in the mortgage default rates.

Fannie and Freddie had heavy involvement with the creation and funding of residential mortgages and one of the primary mortgage derivatives, the mortgage-backed security (MBS). So Fannie and Freddie are deeply in play in the various theories on the cause of the current Recession. The debate has macro-economic implications as theorists argue for various reorganizations of our financial markets and micro-economic implications as the FHFA struggles with what to do with Fannie and Freddie. It matters significantly in these debates whether Fannie and Freddie were victims of, or a primary cause, of the residential real estate value bubble and subsequent collapse.

Available data, and more is coming out as this Article is going to press, suggests that Fannie and Freddie were the villains; the agencies were a primary cause of the domestic real estate bubble. Since the villainy is a product of the endemic structure of the GSEs themselves, the conclusion leads to a recommendation to the winding up both the GSEs (and other similar GSEs) and not use such vehicles in government financial planning. As of the time of writing of this article, the federal government passed the

\footnotetext{
${ }^{5}$ See The Present Condition and Future Status of Fannie Mae and Freddie Mac, supra note 2, at 6 (statement of James B. Lockhart III, Director, Federal Housing Finance Agency).

${ }^{6}$ U.S. DEP'T OF THE TREASURY, OFFICE OF INT'L AFFAIRS, MAJOR FOREIGN HOLDERS OF TREASURY SECURITIES (2008), available at http://www.ustreas.gov/ tic/mfh.txt.

${ }^{7}$ Federal Hous. Fin. AgENCY, RePORT to CONGRESS: 2009, at 6 (2009). See also Future of the Mortgage Market and Housing Enterprises, supra note 3, at 5.
} 
mammoth financial restructuring plan to "stop future financial crises" and the 2000-page bill omits any solution to our GSE problem. ${ }^{8}$

\section{A BRIEF History OF FANNIE AND FREDDIE}

The detailed history of Fannie Mae and Freddie Mae has been well told many, many times. The history is a wandering one, exhibiting at times grand plans and at times incremental political tinkering. In the end, Congress backed itself into a corner, creating two unworkable entities that are so enmeshed in the economy that any change to them is fraught with significant risk. It will take substantial political courage to fix this mess and political courage is a very limited commodity at the moment. What is stunning about the historical tale is how cavalierly Congress changed the fundamental organizational nature of the agencies four separate times subsequent to the founding of Fannie Mae in 1938, dramatically changing the GSE management incentives. Theorists of the "path-dependency" of law or of the "mission creep" of regulatory agencies should find fertile ground here in which to grow their theories.

Fannie Mae had its modest origins in 1938; it was created to help an earlier act, the National Housing Act of 1934, work better. ${ }^{9}$ The National Housing Act established the Federal Housing Administration (FHA) and empowered the new agency to insure qualifying mortgages. ${ }^{10}$ The Act decreased lender risk but did not, as hoped, create a national secondary market in mortgages. Congress created Fannie Mae, a new federal agency, to purchase FHA insured mortgages and to resell them to other investors. ${ }^{11}$ It was, in essence, a simple, federally-owned mortgage dealer. Inevitably, Fannie Mae itself came to hold a portfolio of mortgages, its inventory for resale. Later Congress added Veterans Administration (VA) and Farmers Home Administration (FmHA) insured mortgages to Fannie's portfolio. ${ }^{12}$ From this modest acorn grew the oak tree.

\footnotetext{
${ }^{8}$ See Dodd-Frank Wall Street Reform and Consumer Protection Act, Pub. L. No. 111-203 (2010) (codified in scattered sections of the U.S.C.).

${ }^{9}$ For a good history of the 1934 Act, see Peter M. Carrozzo, A New Deal for the American Mortgage: The Home Owners' Loan Corporation, the National Housing Act and the Birth of the National Mortgage Market, 17 U. MIAMI BUS. L. REV. 1 (2008).

${ }^{10}$ Congress originally chartered Fannie Mae as a subsidiary of the Reconstruction Finance Corporation. In 1939 Congress transferred Fannie, along with the FHA, to the new Federal Loan Agency. In 1950 Congress gave supervision of the agency to the new Housing and Home Finance Agency. It remained there until Congress transferred supervisions to a new cabinet-level Department of Housing and Urban Development (HUD) in 1965.

${ }^{11}$ Carrozzo, supra note 9, at 44.

${ }^{12} \mathrm{Id}$.
} 
The first big change occurred in 1954. Fannie Mae was absorbing significant federal funds and Congress did not want to continue to use general revenue to fund the agency's growth. In response, Congress reorganized Fannie Mae to enable the agency to use private funds as well as federal funds. ${ }^{13}$ Congress, in the Charter Act of 1954, empowered Fannie Mae to sell shares and bonds and use the money to purchase mortgages held in its portfolio. ${ }^{14}$ Fannie Mae was also exempted from all state and local taxes, with the exception of property taxes. ${ }^{15}$ With financing limits imposed by annual Congressional budgeting lifted, Fannie Mae exploded, growing exponentially year after year. Only approval of the U.S. Department of the Treasury was required for issuing new debt. ${ }^{16}$

By 1968, Congress did not want Fannie Mae debt included in the public debt figures, which were starting to show an alarming increase due to the expenditures from the Vietnam War. ${ }^{17}$ So, in an ultimate triumph of offbalance sheet financing, Congress, in the 1968 Charter Act, converted the privately funded part of Fannie Mae into a "government-sponsored enterprise," a privately-financed secondary market institution, and split off the residual, much smaller federally-funded part of Fannie Mae into a new agency, the Government National Mortgage Association, Ginnie Mae. ${ }^{18}$ The federal debt no longer reflected the debt issued by Fannie Mae. Fannie used proceeds from the sale of common stock to retire the Treasury-owned preferred stock. Private shareholders, not the United States government, now owned and operated Fannie Mae under a federal corporate charter. ${ }^{19}$ The President did retain the power to appoint five members to the board of eighteen directors, however. ${ }^{20}$ The 1968 Act also empowered the new privately held federal corporation to issue mortgage-backed securities (MBSs). ${ }^{21}$

${ }^{13}$ Elyse Boyle, Note, Eliminating the Risk to Taxpayers: Privatizing Fannie Mae and Freddie Mac, 43 SuFFoLK U. L. REV. 163, 167 (2009).

${ }^{14}$ David Reiss, The Federal Government's Implied Guarantee of Fannie Mae and Freddie Mac's Obligations: Uncle Sam Will Pick Up the Tab, 42 GA. L. REV.

1019,1029 (2008).

${ }^{15} 12$ U.S.C. $\$ 1452(\mathrm{e})(2006)$.

${ }^{16}$ Reiss, supra note 14 , at 1034.

${ }^{17}$ Richard K. Green \& Ann B. Schnare, The Rise and Fall of Fannie Mae and

Freddie Mac: Lessons Learned and Options for Reform 15 (Nov. 19, 2009)

(unpublished manuscript).

${ }^{18}$ Christopher L. Peterson, Fannie Mae, Freddie Mac, and the Home Mortgage

Foreclosure Crisis, 10 LoY. J. PUB. INT. L. 149, 156 (2009).

${ }^{19}$ Mark A. Edwards, Nationalization, De-Nationalization, Re-Nationalization:

Some Historical and Comparative Perspective, 30 PACE L. REV. 124, 142 (2009);

Peterson, supra note 18, at 156.

${ }^{20}$ Wallison \& Calomiris, supra note 3 , at 72 .

${ }^{21} 12$ U.S.C. $\$ 1719$ (d) (2006). 
The 1968 reorganization created a Janus. Fannie's charter and later, after 1970, Freddie's charter, required that they include a disclaimer in all their securities noting that their debt was not an obligation of the United States. $^{22}$ Fannie and Freddie used this disclaimer to tell Congress and federal regulators not to worry; "the government is not on the hook for what we do." The corporations also trumpeted the monitoring of their new private shareholders, who now elected the boards of directors. ${ }^{24}$ Regulatory oversight, granted to the U.S. Housing and Urban Development (HUD), grew lax. ${ }^{25}$ At the same time the GSEs benefited from a carefully nurtured market perception of implicit government banking. ${ }^{26}$ They told Wall Street: "Don't worry, the Government really is on the hook." ${ }^{27}$ The GSEs could sell debt at lower interest rates than private rivals. Risk-averse investors, including pension funds and foreign governments, seeking above Treasury yields flocked into the GSE bonds. ${ }^{28}$ Fannie and Freddie had access to a virtually unlimited source of cheap cash.

But Fannie and Freddie were not birthed as ordinary private corporations. They were given a myriad of competitive advantages over the private players in the secondary mortgage market. ${ }^{29}$ Their charters, for

\footnotetext{
${ }^{22}$ Reiss, supra note 14, at 1023 (determined according to statute). See 12 U.S.C. $\S$ 1455(h) (2006) (law regarding Freddie Mac's obligations and MBSs); Id. § 1719(b) (law regarding Fannie Mae's obligations); Id. $§ 1719$ (d) (law regarding Fannie's MBSs).

${ }^{23}$ Proposals to Improve the Regulatory Regime for Government Sponsored Enterprises: Hearing Before the S. Comm. on Banking, Hous., and Urban Affairs, 108th Cong. 2-iii (2004) (statement of Hon. Richard S. Carnell, Assocate Professor, Fordham Law School) [hereinafter Proposals to Improve the Regulatory Regime]. Other leading critics of the implied guarantee include Peter Wallison, Thomas H. Stanton and Bert Ely. See, e.g., Peter J. Wallison Et Al., Privatizing FanNiE MAE, FreddE MAC, AND THE FEDERAL HOME LOAN BANKS (2004).

${ }^{24}$ Grant S. Nelson, Confronting the Mortgage Meltdown: A Brief for the Federalization of State Mortgage Foreclosure Law, 37 PEPP. L. REV. 583, 615 (2010).

${ }^{25}$ Fannie and Freddie were regulated by the U.S. Department of the Treasury, which approved their sale of bonds by the HUD, and the Office of Federal Housing Enterprise oversight (OFHEO). Not only did treasury never deny any of Freddie and Fannie's requests, but HUD reviewed new programs far less frequently than it purported to do so. OFHEO was an independent agency created in 1992 and launched with HUD. It was tasked with overseeing the "safety and soundness" of the GSEs, although the office eventually proved to be anemic. See, e.g., Reiss supra note 14 , at 1034 .

${ }^{26} \mathrm{Id}$. at $1043-44$.

${ }^{27}$ Proposals to Improve the Regulatory Regime, supra note 23, at 2-iii.

${ }^{28}$ David Schmudde, Responding to the Subprime Mess: The New Regulatory Landscape, 14 FORDHAM J. CORP. \& FIN. L. 709, 741 (2009).

${ }^{29}$ See David J. Reiss, Fannie Mae and Freddie Mac: Creatures of Regulatory Privilege, 61 ALASKA L. REV. (forthcoming 2010).
} 
example, exempted them from federal securities laws, saving registration fees for issuing securities and avoiding SEC disclosure requirements, ${ }^{30}$ and exempted them from most state and local taxes. ${ }^{31}$ The Secretary of the Treasury is authorized to purchase Fannie and Freddie debt and once purchased the debt becomes an obligation of the federal government. ${ }^{32}$ Federal law enables fiduciaries to invest in Fannie and Freddie obligations as if they were government securities. $^{33}$ Money market funds' diversification requirements do not apply to Fannie and Freddie obligations. $^{34}$ The Federal Reserve Banks acts as Fannie and Freddie's fiscal agents, the same role they play for the federal government. ${ }^{35}$ Finally Fannie and Freddie were exempt from the three percent capital/asset ratio requirement of the FDIC Bank Holding Company Act that governs the solvency of financial institutions. ${ }^{36}$

The third major change came in 1970. Congress, in the Emergency Home Finance Act of 1970, removed the last major leash. Congress significantly enlarged Fannie and Freddie's operating authorization. Both Fannie Mae and the newly minted Freddie Mac received authorization from Congress to purchase and securitize conventional mortgages as well as government-insured or guaranteed mortgages. ${ }^{37}$ The FHA no longer limited what Fannie and Freddie could buy. When traditional lenders, banks, did not have the capital to keep up with the demand for home mortgages in the early $80 \mathrm{~s}$, Fannie and Freddie stepped into the breach by brokering and underwriting residential mortgage-backed securities (RMBSs), the so-called "securitization" of residential mortgages. ${ }^{38}$ The final authorization to dabble fully in the private mortgage market came in 1984 when Congress

${ }^{30} 15$ U.S.C. $\S 78 \mathrm{c}(42)(\mathrm{C})$ (2006). Fannie did agree, voluntarily, in 2004 to comply with several of the SEC disclosure requirements; Freddie filed its first SEC report the month before it collapsed in 2008 .

31 U.S.C. $\S 1452(\mathrm{e})(2000)$.

${ }^{32} \mathrm{Id} . \S 1455(\mathrm{c})(1),(5)$.

${ }^{33} I d . \S \S 1452(\mathrm{~g}), 1455(\mathrm{e})(1), 1723 \mathrm{c}$.

${ }^{34}$ No more than five percent of the assets of a money market fund may be from any one issuer, except Fannie and Freddie. Some funds held a majority of their assets

in Fannie and Freddie debt.

${ }^{35} 12$ U.S.C. $\S 1452(d)$.

${ }^{36}$ Capital Adequacy Guidelines for Bank Holding Companies, Tier 1, 12 C.F.R. $\S$ 225 app.D (2010).

${ }^{37}$ Reiss, supra note 14 , at 1030.

${ }^{38}$ Freddie Mac issued its first MBS in 1971 and Fannie Mae issued its first MBS in 1981. See FRANK FABOZZI \& FRANCO MODIGLIANI, MORTGAGE AND MORTGAGEBACKED SECURITIES MARKETS 21-23 (1992). 
gave Fannie the power to purchase and deal in subordinate lien (second) mortgages. ${ }^{39}$

To create the RMBSs secondary mortgage market, firms purchased and pooled mortgages from primary market lenders (often banks and S\&Ls) and sold securities backed by the mortgage payments to public market investors. ${ }^{40}$ The investor cash fueled the secondary mortgage firm purchases from the primary market originators, which in turn fueled the primary market originators loans to home buyers. Mortgage capital was limited only by the appetite of the public trading markets. The actions of Fannie and Freddie in such securitizations were mimicked by institutional investors, who sold "private label" RMBSs, those issued without a government or GSE guarantee that only Ginnie, Fannie or Freddie could give, and the securitization market for mortgages went into overdrive. ${ }^{41}$

In the 1970 Act, Congress also created a competitor to Fannie Mae, Freddie Mac, to form a secondary market for S\&L mortgages (Fannie Mae purchased exclusively from FHA and VA mortgages from mortgage bankers). ${ }^{42}$ Fannie and Freddie now both purchase mortgages from all comers; their purchasing practices have converged. In 1989, Freddie was also converted into a privately held company, traded on the NYSE and subject to HUD oversight. ${ }^{43}$ In most of the events described in the text, Fannie played the lead role and Freddie followed along behind (sometimes by a few years). The focus hereafter will be on Fannie's activities, with Fannie's and Freddie's numbers aggregated when appropriate.

The fourth change came in 1992. Congress, in the Federal Housing Enterprises Financial Safety and Soundness Act of 1992, created the quasiindependent Office of Federal Housing Enterprise Oversight (OFHEO) within HUD and gave it responsibility to ensure that Fannie and Freddie were "adequately capitalized and operating safely." 44 Congress funded with OFHEO with assessments on Fannie and Freddie. The 1992 Act also established HUD-imposed housing goals for the financing of "affordable

\footnotetext{
${ }^{39}$ See 12 U.S.C. $\S 1454(\mathrm{a})(4)(\mathrm{A})-(\mathrm{C})$ (2006) (granting Freddie permission to deal in second mortgages); Id. $\S 1717(\mathrm{~b})(5)(\mathrm{A})-(\mathrm{C})$ (granting Fannie permission to deal in second mortgages).

${ }^{40}$ Reiss, supra note 14 , at 1028 (describing the process in three steps).

${ }^{41}$ Id. at $1030-31$.

${ }^{42}$ Id. at 1029.

${ }^{43}$ Marsha Courchane et al., Industry Changes in the Market for Mortgage Loans, 41 CONN. L. REV. 1143, 1150 (2009) (The Federal Home Loan Bank System and its member thrifts originally owned Freddie Mac. It is now a publicly-traded company like Fannie Mae.).

${ }^{44}$ The Federal Housing Enterprises Financial Safety and Soundness Act of 1992, § 1303,12 U.S.C. $\S 4502$.
} 
housing," housing in central cities, and housing in rural and "other underserved" areas. ${ }^{45}$ HUD periodically thereafter raised the goals.

The GSEs effectively captured OFHEO, the new agency. ${ }^{46}$ The GSEs played off their shareholders against the OFHEO over who had effective control and began a very effective program of political donations to curry support in Congress. Presidential appointments to the GSE boards were patronage plums. A section of the board of the GSEs came to look like a who's who of out-of-work politicians. Rahm Emanuel, for example, the current Chief of Staff for President Obama held a board position at Freddie in 2000 and 2001, after he left his position as senior advisor to President Clinton and before his successful run for a House seat. ${ }^{47}$

The 1992 Act's affordable housing goals were an outgrowth of the Community Reinvestment Act of 1977 (CRA) that required federally insured commercial banks, as a quid pro quo for being covered by the FDIC, ${ }^{48}$ to lend to borrowers in low and moderate income neighborhoods. Regulatory agencies pressured regulated banks and thrifts to meet the affordable housing goals. ${ }^{49}$ Enforcement was conducted through agency threats not to approve mergers and acquisitions requests, and threats not to approve new operational programs. The CRA goals were referenced explicitly in the 1992 Act that established affordable housing goals for Fannie and Freddie. ${ }^{50}$

The 1992 Act was a watershed in the life of the GSEs. Prior to the 1992 Act the CEOs of the GSEs were acutely aware of political pressures, primarily from Republicans and from free-market economists, to revoke their federal charters and privatize the firms as for-profit state corporations. As ordinary corporations the GSEs would lose the many perks associated with the federal charter, particularly the "implicit federal government guarantee" that enabled the GSEs to place debt interest rates lower than their private competitors. ${ }^{51}$ To save their federal charter the GSEs decided to enter into the lobbying arena in a big way. But selling the agencies' liquidity function in the secondary mortgage markets was not very jazzy. The GSEs could sell, however, the GSEs ability to open up affordable housing for distressed neighborhoods and for lower to middle income

\footnotetext{
${ }^{45} 12$ U.S.C. $\$ 4564$ (2006).

${ }^{46}$ See Thomas H. Stanton, Government-Sponsored Enterprises: Reality Catches Up to Public Administration Theory, 69 PUB. ADMIN. REV. 632, 632 (2009).

${ }^{47}$ Rahm Emanuel Biography, BIOGRAPHY.COM, http://www.biography.com/ articles/Rahm-Emanuel-381074?part $=0$.

${ }^{48}$ In 1995 Congress applied the CRA affordable housing guidelines to all banks.

${ }^{49}$ Ben S. Bernanke, Chairman of the Fed. Res. Sys. Speech, The Community Reinvestment Act: Its Evolution and New Challenges, at the Community Affairs Research Conference (Mar. 30, 2007).

${ }^{50} 12$ U.S.C. $\$ \S 4562-64$ (2006).

${ }^{51}$ Fannie and Freddie Ride Again, ECONOMIST, July 5, 2007.
} 
owners. ${ }^{52}$ Community groups applauded and the GSEs became the toast of the inner city Democrats. Fannie CEO Jim Johnson ${ }^{53}$ opened his campaign in 1991 with an eye catching announcement of a $\$ 10$ billion "Opening the Doors to Affordable Housing" initiative. ${ }^{54}$ He convinced Congress in the 1992 Act to include a mandate for the affordable housing goals of the GSEs. The 1992 Act put Fannie (and Freddie) in direct competition with its original 1938 client, the Federal Housing Administration (FHA). ${ }^{55}$ Two years after the 1992 Act CEO Johnson doubled down and announced a staggering new goal of $\$ 1$ trillion for its "Opening Doors" initiative. ${ }^{56}$ The FHA loan insurance business struggled and began to erode severely after 2000. With the government takeover of Fannie and Freddie, FHA was resurrected in $2009 .^{57}$

It was lobbying genius; Johnson saved the GSE federal charters, but began our inevitable march to the cliff-the current collapse of the real estate market bubble. Fannie and Freddie thereafter progressively loosened, over a sixteen-year period, their qualifying loan requirements and portfolio risk limits. ${ }^{58}$ All the structural incentives were in place by early 2000 to create a

${ }^{52}$ Edward Pinto, Government Housing Policies in the Lead-up to the Financial Crisis: A Forensic Study 50 (Aug. 14, 2010) (unpublished manuscript), available at http://www.aei.org/docLib/Pinto-Government-Housing-Policies-Crisis.pdf.

${ }^{53} \mathrm{Jim}$ Johnson played a major role in creating our current problems. Before joining Fannie he was a managing director at Lehman Brothers and while there handled the Countrywide Financial account. Lehman and Countrywide failed because of their investments in the subprime mortgage market. He thus had a hand in the failure of four (including Fannie and Freddie) of the largest financial companies in the world. His failures are not confined to the private side. He was the campaign manager for Walter Mondale's failed 1984 presidential bid and chaired the vice president selection committee for the presidential campaign of John Kerry. Then Senator Barack Obama appointed him to chair his vice president selection committee for one day, before withdrawing the appointment when it was reported that he had received loans directly from the CEO of Countrywide. The OFHEO found that during his tenure at Fannie he received bonuses based on cooked earnings reports and that Fannie had underreported his total compensation. Afterwards, he moved on to be on the board of Goldman Sachs, Target Corporation, and several other major corporations. He is now vice chairman of a private banking firm, Perseus LLC. For an article on Johnson's lobbying activities at Fannie, see Matthew Cooper, A Medici With Your Money: Fannie Mae's Strategic Generosity, SLATE, Feb. 23, 1997, http://www.slate.com/id/2423.

${ }^{54}$ Pinto, supra note 52, at 66.

${ }^{55} \mathrm{Id}$. at 54.

${ }^{56} I d$. at 66.

${ }^{57}$ See Marsha Courchane et al., Industry Changes in the Market for Mortgage Loans, 41 CONN. L. REV. 1143, 1175 (2009) (describing the declining market share of FHA).

${ }^{58}$ Peter J. Wallison, The True Origins of the Financial Crisis, 13 AEI ON THE ISSUES 7, 8 (2009). 
financial mess. ${ }^{59}$ There were no effective oversight controls over Fannie and Freddie management by shareholders, debt holders or regulatory authorities. Fannie and Freddie management had access to cheap money to invest in a rapidly growing market that generated easy returns. And management was subject to heavy political pressure to grow as fast and as quickly as it could in the riskiest corners of the new market. GSE leverage soared and its underwriting standards eroded.

The opening undeniable warning of severe management problems came in 2003 when Freddie Mac announced that it would have to restate its earnings for 2000-2002..$^{60}$ In 2004 OFHEO reported widespread accounting fraud at Fannie Mae and later that year Fannie agreed to restate its earnings back to $2001 .^{61}$ Fannie managers' compensation bonuses were tied to earnings. As earnings started to fall in the early 2000s the managers' manipulated Fannie's financial records to maximize their pay and appease their shareholders. ${ }^{62}$

The scandal revealed the extent to which the GSEs were exposed to operational risk (from perverse management incentives) and interest rate risk (on their portfolio of mortgages and mortgage backed securities). Astonishingly, any Congressional efforts to reform the two GSEs failed until $2008,{ }^{63}$ when the GSEs collapsed.

\section{THE COLLAPSE AND THE CONSERVATORSHIP}

In 2007 the subprime mortgage crisis revealed itself. An increasing number of borrowers in the subprime market could not meet their mortgage payments. Home foreclosures increased and home prices declined as foreclosures added a large inventory of homes to the market. ${ }^{64}$ Tighter lending standards made it more difficult for borrowers to get mortgages.

${ }^{59}$ See Pinto, supra note 52, at 149-51 (providing a long list of elements that fueled the boom and led to the bust of the real estate market).

${ }^{60}$ Reiss, supra note 14 , at 1037.

${ }^{61}$ Id. at 1039.

${ }^{62}$ Regulators filed 101 civil charges against CEO Franklin Raines, CFO J. Timothy Howard, and former controller Leanne G. Spencer to recoup more than $\$ 115$ million in bonus payments and $\$ 100$ million in penalties. The three agreed to pay fines totaling $\$ 3$ million, which were paid by Fannie's directors and officers insurance policies. See Press Release, Office of Fed. Hous. Enterp. Oversight, OFHEO Files Notice of Charges Against Former Fannie Mae Executives Franklin Rains, Timothy Howard and Leanne Spencer (Dec. 18, 2006), available at http://www.alta.org/govt/issues/ 06/RainesNOC121806.pdf.

${ }^{63}$ See Helen Thompson, The Political Origins of the Financial Crisis: The Domestic and International Politics of Fannie Mae and Freddie Mac, 80 POL. Q. 17 (2009).

${ }^{64}$ See Brent J. Horton, In Defense of Private-Label Mortgage-Backed Securities, 61 FLA. L. REV. 827, 831 (2009). 
The depreciation in home prices led to growing losses for Fannie and Freddie, which at the time backed the majority of residential mortgages. ${ }^{65}$ The Treasury and the Federal Reserve granted both Fannie and Freddie access to the Federal Reserve low-interest loans (at rates similar to commercial banks) and authorized Treasury to purchase GSE stock. ${ }^{66}$ Treasury Secretary Henry M. Paulson defended the soundness of the GSEs and told the markets he would defend them in their "current form;, language he would later regret.

The bailout failed. Fannie and Freddie shares continued to plummet in the trading markets, losing close to ninety percent of their value. On July 30, 2008, President Bush signed the Housing and Economic Recovery Act of 2008 abolishing the OFHEO and creating the Federal Housing Finance Agency (FHFA) with power to place the GSE into receivership or conservatorship. $^{6}$ On September 7, 2008, new FHFA director James Lockhart announced that he had put Fannie Mae and Freddie Mac under conservatorship of the FHFA. ${ }^{69}$ Treasury Secretary Paulson, appearing at the same press conference stated that "I attribute the need for today's action primarily to the inherent conflict and flawed business model embedded in the GSE structure, and to the ongoing housing correction."70

In the conservatorship, director Lockhart implemented, among other things, the following steps: ${ }^{71}$

1. The FHFA assumed the power of the boards of directors and management.

2. The CEOs were dismissed and new CEOs appointed.

3. The dividends on the preferred and common stock would be eliminated but the stock would remain outstanding. Payments on debt instruments would continue.

\footnotetext{
${ }^{65}$ See Boyle, supra note 13 , at 172.

${ }^{66}$ See The Present Condition and Future Status of Fannie Mae and Freddie Mac, supra note 2.

${ }^{67}$ Press Release, U.S. Dep't of the Treasury, Statement by Secretary Henry M. Paulson, Jr., on Treasury and Federal Housing Finance Agency Action to Protect Financial Markets and Taxpayers (Sept. 7, 2008), available at http://www.ustreas.gov/press/releases/hpl 129.htm.

${ }^{68}$ Thomas E. Plank, Regulation and Reform of the Mortgage Market and the Nature of Mortgage Loans: Lessons From Fannie Mae and Freddie Mac, 60 S.C. L. REV. 779, 801 (2009).

${ }^{69}$ Press Release, Fed. Hous. Fin. Agency, supra note 1.

${ }^{70}$ Press Release, U.S. Dep't of the Treasury, supra note 67.

${ }^{71} \mathrm{~W}$. Scott Frame, The 2008 Federal Intervention to Stabilize Fannie Mae and Freddie Mac (Fed. Reserve Bank of Atlanta Working Paper Series, Paper No. 2009-13, Apr. 2009), available at http://papers.ssm.com/sol3/papers.cfm? abstract_id=1458662.
} 
4. All political activities, including all lobbying would halt immediately and all charitable giving would be reviewed.

5. Treasury would provide capital as need to correct any net worth deficiencies that Fannie and Freddie would record through 2012. ${ }^{72}$ The GSEs issued senior preferred stock with a ten percent coupon to the Treasury and agreed to issue common stock warrants representing an ownership stake of $79.9 \%$, at an exercise price of $\$ .00001$ per share with warrant duration of twenty years.

6. Each GSE retained mortgage and mortgage backed security portfolio was capped at $\$ 850$ billion as of December 31, 2009 and had to decline by ten percent a year until it reached $\$ 250$ billion.

The FHFA designed the stock and warrants to protect the senior and subordinated debt and the mortgage backed securities of the GSEs. The GSEs existing common and preferred shareholders will bear losses ahead of the government. ${ }^{73}$ Banks that held Fannie and Freddie preferred shares took huge write downs. ${ }^{74}$ The NYSE has delisted the GSE shares. ${ }^{75}$ In addition to the government conservatorship, the Federal Reserve and the Treasury committed to purchasing GSE debt, mortgage backed securities and stock. $^{76}$ The Federal Reserve also committed to extending loans to GSEs at the primary credit rate. ${ }^{77}$

The total obligations of the two GSEs are just over $\$ 5$ trillion. $^{78}$ Compare this to the $\$ 9.5$ trillion of officially reported United States public debt at the time of the takeover. At issue is whether the assets and the liabilities of the two GSEs must now be incorporate into the federal budget planning due to government control of the entities. The international market in credit default swap contracts on U.S. government debt increased a whopping 3.5 basis points after the government takeover, to a record eighteen basis points (up from six in April) in reaction to the concerns

\footnotetext{
${ }^{72}$ The text represents the December 2009 amendment to the original September 2008 commitment. See Press Release, Fed. Hous. Fin. Agency, FHFA Releases Letter on the Status of the Conservatorship of Fannie Mae and Freddie Mac (Feb. 2, 2010) (explaining that the Treasury is committed to each Fannie and Freddie to the greater of $\$ 200$ billion or $\$ 200$ billion plus cumulative new worth deficits experienced during 2010, 2011 and 2012, less any net worth surplus remaining as of December 31, 2012).

${ }^{73}$ Press Release, U.S. Dep't of the Treasury, supra note 67.

${ }^{74}$ Frame, supra note 71.

${ }^{75}$ Press Release, Fed. Hous. Fin. Agency, FHFA Directs Delisting of Fannie Mae and Freddie Mac Stock from New York Stock Exchange (June 16, 2010).

${ }^{76}$ The Present Condition and Future Status of Fannie Mae and Freddie Mac, supra note 2.

${ }^{77}$ Reiss, supra note 29.

${ }^{78}$ The Present Condition and Future Status of Fannie Mae and Freddie Mac, supra note 2 .
} 
about the size of the government bailout. ${ }^{79}$ The net exposure to taxpayers will depend on future housing prices and mortgage default rates. At the time of the takeover, both Fannie and Freddie had positive net worth but first quarter net losses for both GSEs totaled $\$ 33.1$ billion. ${ }^{80}$ They owned or guaranteed fifty-six percent of all single family mortgages in the country, or $\$ 5.4$ trillion of the total $\$ 11.9$ trillion outstanding mortgage debt. ${ }^{81}$

The GSEs had suffered heavy write-downs on their securities portfolio of both private-label mortgage backed securities (PLMBS) ${ }^{82}$ and their own and each other's securities, large loses on their whole loan portfolio, and large losses on their loan guarantees. The combined loses at Fannie and Freddie in the first two full years of the housing crisis, from July 2007 to July 2009 totaled $\$ 165$ billion. $^{83}$ The largest losses stemmed principally from purchases and guarantees of mortgages originated in 2006 and $2007 .{ }^{84}$ The losses were due in large part to substantial home price decreases and correlated mortgage defaults in just four states: Arizona, California, Florida and Nevada. ${ }^{85}$ The losses, soon after the date of the conservatorship, exhausted the value of each company's shareholder equity and began what has become a recurring series of draws on the Treasury commitments to buy senior preferred stock.

The stunning aspect of the bailout/conservatorship was the snap judgment on whom to wipe out and whom to protect. Treasury, by purchasing senior preferred stock, wiped out the stock value of the common shareholders and the outstanding preferred shareholders. Fannie's common stock, valued at eighty-five dollars in mid-2007, now trades for around forty cents and is the nation's hottest penny stock on the market. ${ }^{86}$ Preferred shareholders also suffered huge losses. One would expect that the shareholders lose everything in an insolvency proceeding, so why the fuss? Treasury protected all the debt holders, even those holding junior subordinated debt. ${ }^{87}$ Debt holders in an insolvency proceeding usually

\footnotetext{
${ }^{79}$ Dawn Kopecki, U.S. Considers Bringing Fannie, Freddie on to Budget (Update1), BLOOMBERG, Sept. 11, 2008, $\mathrm{http} / /$ www.bloomberg.com/apps/news?pid=newsarchive\&sid=adr.czwVm3ws.

${ }^{80}$ The Present Condition and Future Status of Fannie Mae and Freddie Mac, supra note 2.

${ }^{81} \mathrm{Id}$.

${ }^{82} \mathrm{Id}$. at $3-5$.

${ }^{83}$ Future of the Mortgage Market and Housing Enterprises, supra note 3, at 4.

${ }^{84}$ Id.

${ }^{85}$ Future of the Mortgage Market and Housing Enterprises, supra note 3, at 3. Fannie's total credit losses from the four states, as a percentage of total credit losses in 2009, was a whopping fifty-eight percent; Freddie's was sixty-four percent.

${ }^{86}$ Floyd Norris, Caveat Emptor, Continued, N.Y. TIMES, Aug. 5, 2010, at B1.

${ }^{87}$ Press Release, U.S. Dep't of the Treasury, Fact Sheet: Treasury Senior Preferred Stock Purchase Agreement (Sept. 7, 2008), available at
} 
suffer substantial losses, with junior debt holders often absorbing huge losses that can approximate the losses of the preferred shareholders. New credit (e.g., debtor in possession financing) routinely takes priority over all the old creditors as well as the shareholders. The new advanced priority capital allows the firm to stabilize and reorganize. So why did Treasury step in to protect the debt holders and not the shareholders?

The answer is hard to digest and very controversial. Treasury bailed out existing creditors to make explicit the previously implicit government guarantee of Fannie and Freddie. ${ }^{88}$ The implicit guarantee had enticed foreign banks and governments to buy Fannie and Freddie bonds as alternatives to U.S. Treasuries. ${ }^{89}$ Continuing purchases of Treasuries by some of the governments, China and Japan, were essential to the Treasury's continuing ability to sell its debt to finance the U.S. government's huge deficits. ${ }^{90}$ Foreign banks used Fannie and Freddie bonds to meet capital requirements that they had to meet to stay in business (make loans). A downgrade of Fannie and Freddie debt could dry up credit in foreign economies, economies that buy U.S. exports and hold our dollars.

Threatened by political and economic crisis, Treasury immediately caved. The merits of this snap decision will be the subject of debate whenever and wherever financial history is taught and studied. I personally believe the decision to be rushed, panicky, and poorly thought-out. At minimum, Treasury should have negotiated concessions from creditors before it announced the conservatorship; it had time. More importantly, why did Treasury give up normal debtor-in-possession financing giving time for a proper reorganization? I believe we would now be much better off had Fannie and Freddie been formally and properly reorganized using traditional Chapter 11 methods and strategies. The new message to the world: our formal financial rules can be gamed if enough political pressure can be put on Treasury.

But note the identity of those who did not get the benefit of Treasury's good will. Pension plans and domestic banks (usually regional banks) in large numbers held Fannie and Freddie preferred stock, believing the stock

http://www.ustreas.gov/press/releases/reports/pspa factsheet_090708\%20hp1128.p df.

${ }^{88}$ See The Present Condition and Future Status of Fannie Mae and Freddie Mac, supra note 2 (stating that "the Senior Preferred Stock Purchase Agreements have given investors confidence that there is an effective guarantee of GSE obligations ....").

${ }^{89}$ See Jason Thomas, An Assessment of Fannie Mae and Freddie Mac's Contribution to the Financial Crisis of 2008 (George Washington Univ., Dep't of Fin., Dec. 14, 2009).

${ }^{90}$ See Thompson, supra note 63. 
was sure to pay the dividends promised. ${ }^{91}$ They also relied on the implicit backing of the GSEs. They were wrong and suffered total losses on their investments. ${ }^{92}$ So the Chinese government and German banks get the benefit of taxpayer dollars and our retirees and local banks did not. This, of course, strikes middle-class taxpayers, once informed of the details of the bailout, as an insane government financial decision. I throw my lot in with the taxpayers.

\section{EVIDENCE OF FANNIE AND FREDdiE's CAUSE of THE COLlAPSE OF THE MORTGAGE-BACKED SECURITIES MARKET}

The Federal Reserve Open Market Committee, to stimulate the economy, dropped significantly the federal funds target rate, the rate at which banks loan money to each other, in 1997-1998 and again in 2001. ${ }^{93}$ The Federal Reserve then used its Open Market Operations to make the federal funds effective rate follow the federal funds target rate. ${ }^{94}$ Reducing the federal funds rate increases the money supply, lowers banks costs of raising capital, and stimulates bank lending. Artificially low rates give banks the opportunity to print money by borrowing low and lending high. But the banks need to find borrowers; real estate purchasers are and always have been prime candidates.

Comfortable money for banks came from matching the cash flows on the dollars borrowed and on those loaned, but serious money for banks came from factoring the loans (selling them for cash) and reinvesting the new money in new loans, which were again factored and so on-creating an accelerating vortex of money and credit. ${ }^{95}$ When large investors no longer had the appetite to buy the whole loans, the loans were pooled and slices of the pooled and loan returns sold as securities (securitized) to the public markets as MBSs or derivative securities. ${ }^{96}$ Those securities could themselves be pooled and re-sliced and sold to the public markets (as

\footnotetext{
${ }^{91}$ Fannie Mae, Freddie Mac Preferred Stock Losses, MADDOX HARGETT \& CARUSO, P.C. BloG (Nov. 30, 2009, 12:41 PM), http://www.investorprotection.com/blog/2009/11/30/fannie-mae-freddie-macpreferred-stock-losses/.

${ }_{92} I d$.

${ }^{93}$ See Historical Changes of the Target Federal Funds and Discount Rates, FED. RES. BANK OF N.Y., http://www.ny.frb.org/markets/statistics/dlyrates/fedrate.html (last visited Oct. 25, 2010).

${ }^{94}$ See Federal Funds Data Historical Search, FED. RES. BANK OF N.Y., http://www.ny.frb.org/markets/omo/dmm/historical/fedfunds/index.cfm (last visited Oct. 25, 2010) (inputting date range Jan. 1, 2001-Dec. 31, 2001 and selecting data fields "Daily Effective Rate" and "Target Rate").

${ }_{95}$ See, e.g., Reiss, supra note 14 , at 1028 (describing this as step two in the mortgage origination process).

${ }^{96} I d$. (describing this process as step three in the mortgage origination process).
} 
collateral debt obligations: $\mathrm{CDOs}$ and $\mathrm{CDOs}$ squared) ${ }^{97}$ When the markets ran out of securities backed by real assets, banks created synthetic CDOs backed by promises to pay based on the price of referenced pools of real assets (raw bets on the price of MBSs or even CDOs). ${ }^{98}$ In short, the artificially low interest rates created a strong pull on the banks to find and invest in mortgage loans.

The mortgage loans had to be sound (with predictable and reasonable rates of default), however, otherwise the owners of the MBSs and CDOs would lose money and the market for the derivatives would collapse (which it did in 2008). But, and here's the rub, the demand side pressure for mortgage loans had a feed-back loop effect on housing prices, pushing them up artificially, which in turn had an inherently negative effect on the quality of the loans themselves. ${ }^{99}$ Loan collateral, the homes, was inherently overvalued. Moreover, the demand side appetite put pressure on the primary market to loosen underwriting standards, a pressure that could have been and should have been resisted..$^{100}$ But Fannie and Freddie, which could have been an instrument of resistance (refusing to act as a secondary market player in loans that were too risky), became an instrument of its destruction. When the financial crisis hit in 2008, an astonishing forty-nine percent of the nation's outstanding family-mortgage loans had high risk characteristics, making default more likely, ${ }^{101}$ and Fannie and Freddie owned a majority of them. ${ }^{102}$ In short, Fannie and Freddie became the primary demand side player in excessively ${ }^{103}$ risky loans; over a sixteenyear period from 1992 until 2008, they stimulated the risky loan origination market. $^{104}$

${ }^{97}$ CDOs are securities comprised of rated tranches from private MBSs. CDOs squared are securities comprised of rated tranches from CDOs. See Richard E. Mendales, Collateralized Explosive Devices: Why Securities Regulation Failed to Prevent the CDO Meltdown, and How to Fix It, 2009 U. ILL. L. REV. 1359 (2009).

${ }^{98}$ For an easy read on the role CDOs played in the market crisis see, MICHAEL LEWIS, The Big ShorT (W. W. Norton \& Co., 1st ed. 2010).

${ }^{99}$ See Mendales, supra note 97 , at 1393-94

${ }^{100}$ Id. at 1393 .

${ }^{101}$ Pinto, supra note 52, at 17.

${ }^{102}$ Id. at 60 fig. 22,76 fig. 28.

103 "Excessively" is defined as loans that are not priced appropriately for their high risk.

${ }^{104}$ For a similar analysis but using economic theory, see Frederic A. Pelouze, Fannie Mae and Freddie Mac and the 2008 Financial Crisis (Working Paper Series, April 2009), available at http://ssm.com/abstract=1424456 (moral hazard); Andrew T. Young, A Government-Sponsored Crisis: How Fannie and Freddie Caused the Recession (W. Va. Univ., Dep't of Econ., May 3, 2010), available at http://ssm.com/abstract $=1599642$ (adverse selection). 
Consider the GSEs' financial position in late $2007 .^{105}$ Historically, an eighty percent loan-to-market value of the property (LTV) is usually considered a secure mortgage loan; the owners must supply twenty percent of the purchase price. By 1992, banks seemed to have accepted as reasonable a ninety percent LTV. Yet, over the period of 1992 to 2007 Fannie and Freddie acquired $\$ 1.3$ trillion in home purchase loans with a ninety-five percent LTV or more, an eye-popping sixty-two percent of all such high LTV loans originated over the same period. ${ }^{106}$ By the mid-2000s, the zero down to three percent down loans became the dominant form of residential mortgages. ${ }^{107}$ Fannie and Freddie were the primary buyers of these loans. These loans are now defaulting at seven to eight times the level of traditionally underwritten loans with a LTV of ninety or less. ${ }^{108}$ Fannie began buying ninety-seven percent LTV loans in 1994 and onehundred percent LTV loans in 2000. ${ }^{109}$ To make matters worse, from 1997 to 2007 the GSEs acquired $\$ 2.2$ trillion in de facto subprime loans $(\$ 1.5$ trillion) ${ }^{110}$ and private label securities (PLSs) backed by actual subprime loans ( $\$ 700$ billion). ${ }^{111}$ The dollar amounts of de facto subprime loans and of PLS backed by subprime loans purchased by the GSEs were 1.5 times the total of subprime PLSs otherwise held in the markets. ${ }^{112}$ The de facto

${ }^{105}$ The data comes from Edward Pinto, How Did Paul Krugman Get It So Wrong? (Nov. 9, 2009) (unpublished manuscript), http://www.scribd.com/doc/22327819/ Pinto-How-Did-Paul-Krugman-Get-It-So-Wrong-11-9-09. See also Edward Pinto, Here is the Answer to the Question You Asked (Oct. 9, 2009) (unpublished manuscript). For a view contrary to this paper, see Thomas, supra note 89 (private market players were the main culprits in the collapse); Peterson, supra note 19. For an effective rebuttal, see Brent J. Horton, In Defense of Private-Label MortgageBacked Securities, 61 FLA. L. REV. 827 (2009) (government competition with the private markets drove race to high risk).

${ }^{106}$ Pinto, How Did Paul Krugman Get It So Wrong?, supra note 105, at 1.

${ }^{107}$ See Noelle Knox, First Rung on Property Ladder Gets Harder to Reach, USA TODAY, July 17, 2007, at 1A.

${ }^{108}$ They have a serious delinquency rate of $11.56 \%$ compare with a serious delinquency rate of $1.8 \%$ for traditional loans. Derived from data found at Fannie Mae, 2009 Third Quarter Credit Supplement (Nov. 5, 2009), http://www.fanniemae.com/ir/pdf/sec/2009/q3credit_summary.pdf.

${ }^{109}$ Pinto, How Did Paul Krugman Get It So Wrong?, supra note 105, at 1.

${ }^{110}$ These were loans in which the borrowers had a credit score, a FICO score, of less than 660. FICO scores were invented in 1989 and have become the common means for evaluating a borrower's credit history. The definition of subprime in theory excludes any loans that Fannie and Freddie purchase as whole loans but Fannie and Freddie began to purchase loans that looked very much like subprime loans, classifying them as "prime," and rendering the two terms largely useless as an indicator of loan risk in its portfolio. The practice caused considerable confusion among those trying to assess Fannie and Freddie role in the mortgage meltdown. See Id.

${ }^{111} I d$.

${ }^{112} I d$. at 2. 
subprime loans are now defaulting at eight to nine times the level of traditionally underwritten loans, ${ }^{113}$ and the subprime PLSs are defaulting at eighteen to nineteen times the level of the GSEs traditionally underwritten loans. ${ }^{114}$ The GSEs also stumbled into the Alt-A market: Over the period from 2002 to 2007 the GSEs acquired $\$ 773$ billion in de facto Alt-A loans ${ }^{115}$ and private securities backed by actual Alt-A loans, fifty-five percent of all such loans originated nationwide over the period. ${ }^{116}$ The loans are now defaulting at nine to ten times the level of the GSEs traditionally underwritten loans. ${ }^{117}$

How did Fannie and Freddie work its way into such a precarious position? It started with the HUD affordable housing mandates under the 1992 Act, the "Federal Housing Enterprises Financial Safety and Soundness Act." Private banks had been subject to affordable housing goals since 1977 and in 1992 the goals also applied Fannie and Freddie. ${ }^{118}$ With banks anxious to meet the goals and Fannie and Freddie anxious to meet the goals, there was only one way to do it-relax lending standards in the targeted distressed communities and among targeted borrowers. So began the use of "flexible" or "innovative" lending standards to allow for the acceptances of loans of more than ninety-seven percent LTV, of loans to those with impaired credit, high debt ratios, and "creative" (questionable) income potential. ${ }^{119}$ Loans so made were tagged as "goals rich" loans. ${ }^{120}$ Originating banks lowered lending standards for CRA loans, counting the loans towards their affordable housing goals, and sold close to fifty percent of the total CRA originations from 2000 to 2007 to Fannie and Freddie,

\footnotetext{
${ }^{113}$ These traditionally underwritten loans have a FICO of over 660. They have a serious delinquency rate of $16.08 \%$ if the FICO is less than 620 and a delinquency rate of $11.32 \%$ if the FICO is less than 660 but more than 620 . Fannie Mae, supra note 108.

${ }^{114}$ Pinto, How Did Paul Krugman Get It So Wrong?, supra note 105.

${ }^{115}$ An Alt-A loan is a risky loan, riskier than prime but less risky than subprime, that does not meet the GSEs traditional purchasing requirements due to its size or other factors about the loan that is not related directly to the borrower's credit history. Fannie and Freddie purchased loans that were classified as prime when in fact they were Alt-A.

${ }_{116}$ Pinto, How Did Paul Krugman Get It So Wrong?, supra note 105, at 1. ${ }^{117} \mathrm{Id}$.

${ }^{118}$ See 12 U.S.C. $\$ \S 4562-64$ (2006). The term "enterprise" as used in these sections means Fannie Mae and Freddie Mac. 12 U.S.C. § 4502(6) (2006).

${ }^{119}$ Pinto, How Did Paul Krugman Get It So Wrong?, supra note 105. The traditional "Three C's" of mortgage credit are collateral, character, and capacity. Collateral is represented by down payment percentage or loan-to-value (LTV); character is credit history of the borrower; capacity is the mortgage debt ratio to income and total debt ratio to income and stability of income of the borrower. All three C's weakened substantially in the sixteen years from 1992 to 2008 .

${ }^{120}$ See Thomas, supra note 89, at 14.
} 
which used the loans to meet their affordable housing goals as well. ${ }^{121}$ Moreover, Fannie and Freddie bought PLSs backed by subprime loans with CRA originations to count them towards their affordable housing goals. ${ }^{122}$ Keep in mind that Fannie and Freddie were more than willing participants in the affordable housing goals, they asked for them so as to establish a favorable lobbying position in Congress to protect their privileged federal charters.

On June 18, 2009, the National Mortgage News reported that James Lockhart III, the first directors of the FHFA, acknowledged that, "[in] retrospect" the affordable housing goals "caused [Fannie and Freddie] to do things they shouldn't have done.,"123

Had the banks and Fannie and Freddie limited the loosening of their underwriting standards to CRA loans, the mortgage crisis would not have been a crisis. However the lowered underwriting standards inflected all underwriting standards. ${ }^{24}$ If CRA lending could use the lower standards, why not apply the lower standards to non-CRA lending? Why not make high LTV loans on condos in Florida and retirement homes in Arizona? The cheap money from the Federal Reserve was there for these purchases as well. From 1992 to 2007 the percentage of conventional purchase money mortgages with the borrower putting less than ten percent down more than tripled. ${ }^{125}$ Home ownership, level for over thirty years, grew from $64.2 \%$ of the population to a peak in 2004 of $69.2 \%$ of the population. ${ }^{126}$ In the end, the loan culture collapsed-no risk was too high to underwrite. "Liar's loans," 127 loans granted without any documentation from the borrower and without any verification from the originator, represented the pinnacle of the folly.

Fannie and Freddie shareholders relied on the federal regulators for monitoring company soundness. Fannie and Freddie debt holders relied on

\footnotetext{
${ }^{121}$ See Pinto, How Did Paul Krugman Get It So Wrong?, supra note 105, at 1. ${ }^{122}$ See id.

${ }^{123}$ Letter to the Editor, GSEs' AH Goals, NAT'L MORTGAGE NEWS, July 13, 2009, at 6.

${ }^{124}$ Pinto, How Did Paul Krugman Get It So Wrong?, supra note 105.

${ }^{125}$ EDWARD PINTO, THE GAO's ANALYSIS OF THE GOVERNMENT CORPORATION FOR AGENCY OPTION AS A REPLACEMENT STRUCTURE FOR THE GSES (Sep. 24, 2009).

${ }^{126}$ Pinto, supra note 52, at 23.

${ }^{127}$ Liar's Loans are the "low-doc" or "no-doc" mortgages. These are loan programs are designed for borrowers who have a hard time producing income and asset verifying documents, such as prior tax returns. Specifically, loans are called liar loans because the Simple Interactive Statistical Analysis (SISA) or No Income, No Asset (NINA) features open the door for abuse when borrowers or their mortgage brokers or loan officers overstate income or assets in order to qualify the borrower for a larger mortgage.
} 
the implicit government guarantee of their debt. And Fannie and Freddie management captured its primary regulatory agency, the OFHEO, with the effectiveness of its lobbying of and its campaign contributions to members of Congress.

\section{FANNIE AND FREDDIE UNDER GOVERNMENT CONSERVATORSHIP: A Nationalized SECONDARY MorTGage Market, Politicized GOALS AND A FEDERAL RESERVE QUANDARY}

In the first quarter of 2009, after the takeover, Fannie and Freddie's combined share of the purchase of mortgages originated in the quarter was seventy-three percent, reflecting a wholesale withdrawal of private secondary mortgage market players and of banks willing to hold whole loans. ${ }^{128}$ If you add the FHA and the VA loans, the four agencies are now responsible for over eighty-five percent of all new mortgage loans being originated. ${ }^{129}$ The government has nationalized the secondary mortgage market, and by doing so, has effectively nationalized the entire mortgage finance market. The federal government is responsible for the credit risk on $\$ 6$ trillion in mortgage loans. ${ }^{130}$ The amount is fifty-five percent of all outstanding home mortgage debt. ${ }^{131}$ If the home mortgages and MBSs on the balance sheets of FDIC insurance banks, thrifts and other related entities are added, the percentage rises to over eighty-four percent. ${ }^{132}$ Moreover the credit risk on the loans is substantial; as of March 31, 2009, total mortgage debt in the country had a gross LTV ratio of ninety percent, the highest ratio in modern history. ${ }^{133}$

The Directors of the FHFA as conservators of Fannie and Freddie have put in place several major programs. First, the FHFA has strengthened the GSEs underwriting standards, ironically in essence, rolling them back to pre-1992 levels that were in place before the 1992 Act that mandated the affordable housing goals. ${ }^{134}$ The effect on the mortgage market, of course,

\footnotetext{
${ }^{128}$ Press Release, Fed. Hous. Fin. Agency, supra note 72.

129 EDWARD PINTO, FIRST ANNIVERSARY OF THE BAILOUT OF THE GSES:

CONTEMPLATING A MORTGAGE INDUSTRY RELIANT ON GOVERNMENT STIMULUS (Sept. 1, 2009).

${ }_{130}$ Interview by Erik Schatzker, Host of Inside Track, Bloomberg, with Anthony Sanders, Professor, George Mason Univ. (June 14, 2010).

${ }^{131}$ PINTO, supra note 129.

${ }^{132} \mathrm{Id}$.

${ }^{133} I d$.

${ }^{134} \mathrm{See}$ FED. HOUS. FIN. AGENCY, CONSERVATOR'S REPORT ON THE ENTERPRISES' FNAANCIAL PERFORMANCE: SECOND QUARTER 2010, at 6 (2010).
} 
is to tighten lending. Mortgage rates have continued to drop, however, for qualified lenders as banks still have access to cheap money. ${ }^{135}$

Second, the activities of Fannie and Freddie have become intensely politicized. Government ownership begets government pressure to pursue government goals. There are several examples.

The FHFA has implemented a foreclosure holiday program for qualifying borrowers. Known as the Home Affordable Modification Program program (HAMP), Fannie and Freddie announced a willingness to limit monthly mortgage payments to thirty-one percent of a qualified borrower's total pretax monthly income. ${ }^{136}$ The program has thus far been a failure, adding less than 340,000 homeowners, far less than the target group of " 3 to 4 million., 137 The loans targeted by HAMP are so problematic that even the modifications usually will not stave off instant or eventual default. Moreover, the program displaced more effective private sector efforts to modify mortgage loans. ${ }^{138}$

A related program is the Home Affordable Refinance Program (HARP) aimed at helping homeowners refinance if they are current on their payments and lower their mortgage payments by taking advantage of lower mortgage rates in the market. ${ }^{139}$ Homeowners with an LTV of between $80 \%$ and $125 \%$ can qualify and the GSEs will refinance without requiring additional mortgage insurance. ${ }^{140}$ Like HAMP, HARP has had a very limited success.

Now there is concern that the government is taking seriously a proposal by a top Morgan Stanley economist for a "Slam Dunk Stimulus"141 composed of the wholesale refinancing of all Fannie and Freddie mortgages, without regard to the current value of the underlying property of the borrowers' creditworthiness, a sort of "one-time amnesty." If one-half

\footnotetext{
${ }^{135}$ Binyamin Appelbaum, Mortgage Securities it Holds Pose Sticky Problem for Fed, N.Y. TIMES, July 23, 2010, at B1.

${ }^{136}$ See Chad D. Emerson, A Troubled House of Cards: Examining How the Housing and Economic Recovery Act of 2008 Fails to Resolve the Foreclosure Crisis, 61 OKLA. L. REV. 561 (2008).

${ }^{137}$ FED. RES. BANK OF BOS., HAMP LOAN MODIFICATION STATISTICS, available at http://www.bos.frb.org/commdev/foreclosures/data/NE-HAMP201005.pdf.

${ }^{138}$ Foreclosure Preventions Part II: Are Loan Servicers Hononing Their

Commitment to Help Preserve Homeownership?: Hearing Before H. Comm. on Oversight \& Gov. Reform, 111 th Cong. 3 (2010) (statement of Edward J. Pinto). ${ }^{139}$ Future of the Mortgage Market and Housing Enterprises, supra note 3, at 9. ${ }^{140}$ Press Release, Fed. Hous. Fin. Agency, FHFA Authorized Fannie Mae and Freddie Mac to Expand Home Affordable Refinance Program to 125 Percent Loanto-Value (July 1, 2009).

${ }^{141}$ Nick Timiraos, 'Free Stimulus' via Refinancing, Debate Grows, WaLl ST. J. DEV. BLOG (July 30, 2010, 2:11 PM); David Greenlawn, Slam Dunk Stimulus, GLOBAL ECON. F. (July 29, 2010).
} 
the number of government guaranteed mortgages were refinanced, he argued, the new lower rates would put $\$ 46$ billion a year in cash into the pockets of borrowers and it would act as an economic stimulus. ${ }^{142}$ The owners of MBS, of course would take immediate losses on their securities. The position roiled the fixed income market and led Treasury Secretary Geithner to quell thoughts of "major changes." "143 But government ownership of so large a slice of the mortgage market makes it tempting to say the least, to use the position for "silver bullet" economic cure proposals.

Government market power in the secondary mortgage market also has major market implications, just as the market power of any monopolist, public or private, has major implications. To see the use of raw market power and its potential consider the current demands of Fannie and Freddie on large commercial banks for loan repurchases. The GSEs are demanding that the banks repurchase at par some of the toxic loans sold to the GSEs as a condition of continuing to do business with them. ${ }^{144}$ The GSEs argue that the banks made bad loans and then sold the loans to the GSEs under false description. $^{145}$ The threat to suspend business is very potent, making litigation over the circumstances of the loans unnecessary. The banks can plead their case but Fannie and Freddie hold all the cards. If the banks do not persuade the GSEs of their bona fides, the banks have to capitulate and repurchase; litigation is out of the question.

The assumption might be that the mortgage crisis has tightened up underwriting standards across the markets, but there is a major leak. The roll back of the underwriting standards at Fannie and Freddie ${ }^{146}$ have reduced the agencies competition with the FHA, which now has shouldered the mantle of facilitating loans (through federal insurance) to low and middle income borrowers. As the number of FHA loans has skyrocketed, there is a serious question about whether the new FHA loans are themselves going to generate excessively high default rates.' FHA loans of ninetyseven percent or more LTV may comprise over one-fifth of the current total mortgage market. ${ }^{147}$ Expert Edward Pinto estimates that, under a worst

${ }^{142}$ Greenlawn, supra note 141.

${ }^{143}$ Corbett B. Daly, U.S. Treasury-No Change to Fannie, Freddie Policy, REUTERS, Aug. 5, 2010, http://www.reuters.com/article/idUSN0514276420100805.

${ }^{144}$ See Floyd Norris, Sticking Banks with the Bill, N.Y. TIMES, Aug. 20, 2010, at B1.

${ }^{145}$ See, e.g., Fannie Mae, Quarterly Report (Form 10-Q), at 95 (Aug. 5, 2010);

Freddie Mac, Quarterly Report (Form 10-Q), at 65 (Aug. 9, 2010).

${ }^{146}$ See Unfinished Business, ECONOMIST, July 24, 2010, at 71.

${ }^{147}$ See The Future of the Federal Housing Administration's Capital Reserves: Assumptions, Predictions, and Implications for Homebuyers: Hearing Before Subcomm. on the Hous. and Cmty. Opportunity of the H. Comm. on Fin. Servs., 111 th Cong. 8 (2009) (statement of Edward Pinto, Real Estate Financial Services Consultant). 
case scenario analysis, the government may have to bailout the FHA with another $\$ 43$ billion once defaults manifest on its insurance agreements. ${ }^{148}$ The political pressure to subsidize home ownership in targeted communities is too powerful apparently to be affected by anything as minor as a full blown financial crisis.

Finally, the participation of the Federal Reserve in the Fannie and Freddie bailout has produced major regulatory side-effects. An important part of the support of Fannie and Freddie came to be the wholesale purchase of some of their most toxic assets by the Federal Reserve. The Fed bought and now owns close to $\$ 1.1$ trillion of the GSE's mortgage securities. ${ }^{149}$ The proceeds of the sales went to the GSEs who in turn funneled the cash back into the residential mortgage market. The Fed now is in a pickle. ${ }^{150}$ If the Fed holds the securities, it may not have the cash necessary to control interest rates and inflation through its traditional method of purchasing and selling Treasury securities. Moreover, the Fed may lose buckets of money as it holds very low interest securities in a potentially rising interest rate market. Yet if the Fed sells the securities it will book a large loss and drive interest rates up, injuring an already stumbling economy. Most troubling perhaps is the Fed's self-interest in keeping interest rates low to minimize the losses on its own portfolio, a goal in potential conflict with its goal of setting interest rates to further the best interests of the country's markets. For example, the Fed can choose not to fight inflation with interest rate increases, to the benefit of their own portfolio.

\section{WHAT SHOULD WE DO WITH FANNIE AND FREDDIE?}

The government is mulling over what to do with Fannie and Freddie. The President has a taskforce considering the program and Congress has heard testimony from various experts on the matter and from the first two directors of the FHFA. Financial newspapers and journals are full of op-ed pieces containing recommendations. Advocates debate whether Fannie and Freddie should be recast as a government agency, returned to its preconservatorship form as a government sponsored enterprise, or privatized. ${ }^{151}$ The first option would be to nationalize them. If reconstituted as GSEs, the second option, Congress would have to reconsider their missions, making, for example, explicit the government's

\footnotetext{
${ }^{148} I d$. ("[A]dd a required two percent surplus reserve and the number balloons to $\$ 54$ billion.").

${ }^{149}$ See Appelbaum, supra note 135.

${ }^{150} \mathrm{Id}$.

${ }^{151}$ For an argument that all developed countries will inevitably do all of the above, cyclically, see Edwards, supra note 19.
} 
role in re-insurance, and regulation. ${ }^{152}$ Finally, with the third option, complete privatization, Fannie and Freddie could supply liquidity with or without government reinsurance. ${ }^{153}$ The option chosen would have to affect the degree of government regulation. Former Secretary Paulson, for example, has suggested that they be regulated as public utilities. ${ }^{154}$ There are many choices and each choice comes with its own variants and nuances. ${ }^{155}$

In any event, Congress is nearly paralyzed on what to do. The real estate market is in a perilous condition, the GSEs are under government control and operating in a fashion, and any major organization changes could spook the markets. Evidence of Congressional reluctance to act on the question is evident in the 2000 plus page financial reform bill working its way through Congress at the moment. The bill, designed to stop future financial crises, does not deal with Fannie or Freddie and its role in the mortgage crisis. Chairman of the House Financial Services Committee, Barney Frank, has publicly stated that Congress does not need to do anything - it has nationalized, read abolished, the GSEs, stemmed future losses, and need only pay off the old losses. ${ }^{156}$

My recommendation? Return to 1938, with a caveat. In 1938, the FHA, a government agency, was responsible for insuring loans to low and middle income borrowers. ${ }^{1{ }^{3} 7}$ The loan insurance was understood to be a government subsidy for targeted income groups. Cap the insurance

${ }^{152}$ See, e.g., Dwight Jaffee et al., What to Do About Government-Sponsored Enterprises, in RESTORING FINANCIAL STABILITY (2009); Dwight Jaffee \& John M. Quigley, The Government Sponsored Enterprises: Recovering from a Failed Experiment, (Univ. of Cal. Berkeley Inst. of Bus. and Econ. Research. Working Paper No. W09-001, Feb. 2009).

${ }^{153}$ Dwight M. Jaffee, Reforming Fannie and Freddie, REGULATION (Winter 2009); David J. Reiss. Coming Out of Conservatorship: Developing an Exit Strategy for Fannie and Freddie, FINREG21 LOMBARD ST. (2009); Lawrence J. White, On Truly Privatizing Fannie Mae and Freddie Mac: Why It's Important and How To Do It (Wharton Sch. Univ. of Pa. Working Paper June 23, 2005), available at http://fic.wharton.upenn.edu/fic/papers/05/0532.pdf.

${ }^{154}$ Paulson Sees Changes For Freddie and Fannie, N.Y. TIMES, Jan. 8, 2009, at B6.

${ }^{155}$ President Andrew Jackson, when faced with a similar question on what to do with the federally charted Second Bank of the United States, simply vetoed Congress's attempt to re-charter the Bank when its charter was up for renewal. After the veto, the bank became private, shorn of any government privileges. A few years later the bank, trying to support the price of cotton, failed and the government did not bail it out; it died. See Alex J. Pollock, Fan and Fred: What Would Andrew Jackson Do?, WALL ST. J., July 23, 2010, at A15.

${ }_{156}$ Opinion, Barney to Fannie: Drop Dead, WALL ST. J., Aug. 19, 2010, at A16. 157 Jaffee et al., What to Do About Government-Sponsored Enterprises, supra note 152 , at 9 . 
exposure and redefine the targets for the subsidy and empower the FHA to provide the insurance. Fannie Mae, also a government agency in 1938, was, simply put, a liquidity provider in the secondary market, a government broker-dealer in mortgages. ${ }^{158}$ It was a market maker. Return Fannie to its original role but as a private actor with a federal corporate charter.

In the charter Fannie should be prohibited from accumulating a portfolio of mortgage loans except as necessary to act as a dealer, with a view to their timely resale. It should also be prohibited from owning any derivative mortgage-backed securities or any other securities, for that matter, except for the temporary ownership necessary, perhaps, in some securitization underwritings of sales of MBSs to private investors or to the public. ${ }^{159}$ In such a role Fannie would lose its power to insure mortgages or pools of mortgages (except as a clearing house). Fannie would therefore no longer be in competition with the FHA. Fannie would, in essence be a true investment bank, limited to underwriting the resale of mortgage loans and pools of mortgage loans.

Any debt placed by Fannie would not be implicitly or explicitly guaranteed by the federal government and the funds would be used exclusively to fund market making activities. Returns on the debt and equity in Fannie would come solely from fees charged for its market making activities.

In other words, Fannie would play the role of a trading market and clearinghouse for mortgage loans, not unlike the NYSE's function for stocks and bonds and the CBOE function for options. Fannie may eventually have private market competitors. Using a trading market analogy, one does not have to accept a role for Fannie as a guarantor of mortgage debt. In its clearinghouse role it would only guarantee performance on trades of debt by member traders.

Disabling Fannie and Freddie from insuring mortgages or guaranteeing securities backed by mortgages puts my recommendation at odds with the "current consensus" of government and academic economists. 160 The

${ }^{158}$ See Richard E. Mendales, The Fall and Rise of Fannie and Freddie: Securitization After the Meltdown (Oct 15, 2009) (unpublished manuscript), available at http://papers.ssrn.com/sol3/papers.cfm?abstract_id=1489574\# 1239676; Anthony B. Sanders \& Robert Van Order, The Government's Role in Housing \& The Role of Fannie and Freddie: Dueling Missions and Dueling Charters (Aug. 2009) (unpublished manuscript), available at http://mason.gmu.edu/ -asander7/GOV.pdf (they would continue the guarantee function however). ${ }^{159}$ This proposal has widespread support. See, e.g., Thomas E. Plank, Regulation and Reform of the Mortgage Market and the Nature of Mortgage Loans: Lessons from Fannie Mae and Freddie Mac, 60 S.C. L. REV. 779 (2009).

${ }^{160}$ See, e.g., Binyamin Appelbaum, Mortgage Role for U.S. is Affirmed, N.Y.

TIMES, Aug. 18, 2010, at B1; Nick Timiraos, Housing Ills Cloud Debate on Fannie, 
consensus comes with a sense that the mortgage market will not function well without some form of guarantee. The consensus breaks down immediately when the discussion turns to the form of the guarantee, however. Some want coverage of only catastrophic losses, others want only secondary guarantees of private insurers, ${ }^{161}$ others want Fannie and Freddie to sell explicit guarantees at market rates ${ }^{162}$ and yet others want a government insurance fund selling the guarantees. ${ }^{163}$

All the proposals ignore the evidence from other developed countries that show most other countries did not offer mortgage insurance of MBS guarantees and yet have homeownership rates similar to ours. ${ }^{164}$ Furthermore, none of those countries suffered as severe a housing value crash as we did. The most disheartening argument comes from self-styled pragmatists who assert that Congress is no longer capable of resisting calls for bailouts in the housing sector whenever a crisis hits, so we should just put the guarantee in place explicitly to better organize it. ${ }^{165}$

The primary winners of government guarantees and insurance programs are Wall Street financiers who benefit from the trading activity generated by under-priced asset insurance. Cheap insurance translates into trading profits as market players seek to take full advantage of the gains from, in essence; owning and reselling assets supported by the below cost insurance. It should not surprise anyone that the most vocal supporters of the federal insurance and guarantee program are found on Wall Street. Want to make Wall Street happy? Have the government offer free "catastrophic insurance" on all stock trading losses.

There is no doubt that the "cold turkey" elimination of the government guarantees and insurance would push up mortgage interest rates by one or two percent. ${ }^{166}$ The effect on a struggling economy would be negative as house sales and prices would decline further. Those who believe the country cannot suffer the decline want a gradual phase in of any

WALl St. J., Aug. 16, 2010, at A2. But see William Poole, Op-Ed, Say Goodbye to Fannie and Freddie, N.Y. TIMES, Aug. 12, 2010, at A31.

${ }^{161}$ See Appelbaum, supra note 160.

${ }^{162}$ Donald Marron \& Phillip Swagel, Whither Fannie and Freddie? A Proposal for Reforming the Housing GSEs, E21 (May 24, 2010), http://www.economics21.org/ files/pdfs/commentary/05_24_2010_Whither.pdf; Unfinished Business, supra note 146 , at 72 .

${ }^{163}$ Unfinished Business, supra note 146, at 71.

${ }^{164}$ Michael Lea, Alternative Forms of Mortgage Finance: What Can We Learn From Other Countries? 2-3 (Feb. 18, 2010) (unpublished manuscript), available at http://www-rohan.sdsu.edu/ realest/images/Harvard-Lea.pdf.

${ }^{165}$ Unfinished Business, supra note 146, at 71.

${ }^{166}$ PINTO, supra note 129 , at 3. 
elimination. ${ }^{167}$ I think the gradual phase-in programs are a mistake. They would generate a split housing market, the insured and the uninsured, with an excess demand for the insured mortgages and securities. The excess demand will cause political pressure for favored allocations and will cause grey market activity that necessarily follows all artificial price fixing. A better approach would be the promulgation of a new tax credit for approximately one point of residential mortgage interest (on top of the current deduction) that is effective immediately and that is phased out over time (dependent on economic conditions).

The transition to the position I recommend would be remarkably straightforward. Fannie and Freddie would sell off over time their entire portfolio of securities and most all their portfolio of whole loans. Congress would sell its preferred stock to the markets and recharter the GSEs including, among other things, an end the President's power to appoint directors to the board and appropriate limits on the firms' powers. The problem comes in how to unwind the existing GSE guarantees on MBS securities and insurance on whole loans. Two-thirds of the GSE guarantees on MBS securities could simply be voided by the government: The Fed holds $\$ 1$ trillion guaranteed securities, the Treasury holds $\$ 300$ billion in guaranteed securities and Fannie and Freddie hold $\$ 1.6$ trillion in the securities. ${ }^{168}$ The remaining guarantees on securities would have to be renegotiated (bought out), assigned for cash to private insurers, or held to the maturity of the securities. Insured whole loans would get similar treatment.

\section{LESSONS FOR REGULATION}

The saga of Fannie and Freddie provide numerous lessons, both macro and micro, for careful observers of federal government regulation. I list only a few below, those that have caught my attention.

First and foremost is the danger of the federal government giving a generalized boost to a tangible asset-based trading market (in this case the real estate market). The United States market has come to depend on artificial price stimulus from a numerous number of federal plums: personal tax deductions for interest payments on home mortgage debt; federal mortgage insurance; federal deposit insurance for banks that originate and hold home mortgages; federal subsidies for CRA loans-loans in distressed neighborhoods and to low income and middle income wage earners; low

\footnotetext{
${ }^{167}$ See Edward Pinto, The Future of Housing Finance, WALL ST. J., Aug. 17, 2010, at A19 (discussing phase in programs).

${ }^{168}$ Green \& Schnare, supra note 17 , at 2; Marron \& Swagel, supra note 162, at 10; Press Release, U.S. Dep't of the Treasury, Treasury Issues Update on Status of Support for Housing Programs (Dec. 24, 2009), available at http://www.treas.gov/ press/releases/2009122415345924543.htm.
} 
interest credit for banks that make home mortgage loans; insolvency protection for banks that make home mortgage loans that fail (bailouts); and others. The home ownership market is inherently "juiced." The government has found it very difficult, if not impossible politically to fine tuning the support so that it does not create artificial housing price bubbles. Although now practically impossible to extricate the government, I envy those modern economies (Canada and New Zealand, for example) that have never swallowed the whole home subsidy pill. They will have a competitive advantage to the United States over time.

Second, the mission creep of Fannie and Freddie should be a case study for all Congressmen and women and all federal regulators. Regulators should note the ease with which Fannie and Freddie in 1954, 1968, 1992 and 2008 slid from a carefully circumscribed role to the federal nationalization of the entire housing financing market. No one, Presidents and Congress included, has ever wanted the federal government to play such a role, yet here we are. Each step was taken for incremental political expediency: to raise private money, to get the debt off the books, to help distressed neighborhoods, and to assuage the potential anger of powerful foreign governments who are trading partners. No one discussed the long run costs and the potential for calamity; immediate concerns drove each decision.

The solution? Put in place an overall mission plan for agencies that is specific (not a warehouse of general welfare benefits) and notes the effects on all affected trading markets and then buy into it and stick to it.

Finally, when Congress does decide to subsidize target subcommunities in the market, distressed neighborhoods and low-income wage earners, Congress should fashion the subsidy to be transparent and cap it. In other words, Congress must take care to put in place protections against the subsidy leaking out and affecting risk decisions in the larger market. Fannie and Freddie took a CRA subsidy and effectively gave it to everyone, including real estate speculators, second home buyers, and wealthy home owners. No one wanted to subsidize those markets in name of assuaging the negative effects of income disparity. 